\title{
次期固体ロケット空カ特性についての風洞試験*1
}

\section{Wind Tunnel Tests on Aerodynamic Characteristics of Advanced Solid Rocket}

\author{
北村 圭 一 ${ }^{* 2}$ ・藤 本 圭一郎 ${ }^{* 2} \cdot$ 野 中 聡*3 $・$ 入門 朋 子*3 \\ Keiichi Kitamura, Keiichiro Fujimoto, Satoshi Nonaka, Tomoko IriKado, \\ 福 添 森 康 ${ }^{*}$. 嶋 英 志 ${ }^{* 2}$ \\ Moriyasu FukUzoe and Eiji SHIMA
}

Key Words: Advanced Solid Rocket, Aerodynamic Characteristics, Wind Tunnel, Supersonic Flow, Schlieren, Oilflow

\begin{abstract}
The Advanced Solid Rocket is being developed by JAXA (Japan Aerospace Exploration Agency). Since its configuration has been changed very recently, its aerodynamic characteristics are of great interest of the JAXA Advanced Solid Rocket Team. In this study, we carried out wind tunnel tests on the aerodynamic characteristics of the present configuration for Mach 1.5. Six test cases were conducted with different body configurations, attack angles, and roll angles. A six component balance, oilflow visualization, Schlieren images were used throughout the experiments. It was found that, at zero angle-of-attack, the flow around the body were perturbed and its drag (axial force) characteristics were significantly influenced by protruding body components such as flanges, cable ducts, and attitude control units of SMSJ (Solid Motor Side Jet), while the nozzle had a minor role. With angle-of-attack of five degree, normal force of $C_{N \alpha}=3.50 \pm 0.03$ was measured along with complex flow features observed in the full-component model; whereas no crossflow separations were induced around the no-protuberance model with $C_{N_{\alpha}}=2.58 \pm 0.10$. These values were almost constant with respect to the angle-of-attack in both of the cases. Furthermore, presence of roll angle made the flow more complicated, involving interactions of separation vortices. These data provide us with fundamental and important aerodynamic insights of the Advanced Solid Rocket, and they will be utilized as reference data for the corresponding numerical analysis.
\end{abstract}

\begin{tabular}{lll} 
& & \multicolumn{1}{c}{ 記 } \\
$\mathrm{A}$ & $:$ 付着線 (attachment line) \\
$C_{A}$ & $:$ 軸力係数 (=抵抗係数 ; 迎角無しの時) \\
$C_{N}, C_{N_{\alpha}}$ & $:$ 横力係数, 横力係数傾斜 \\
$\mathrm{D}$ & $:$ 機体底面直径 \\
$\mathrm{EW}$ & $:$ 膨張波 \\
$F$ & $:$ 軸力 \\
$\mathrm{L}$ & $:$ 機体全長 \\
$M$ & $:$ マッハ数 \\
$\mathrm{N}$ & $:$ 節点 (nodal point) \\
$N$ & $:$ 横力 (垂直力) \\
$P$ & $:$ 圧力 \\
$q$ & $:$ 動圧 \\
$R e$ & $:$ レイノルズ数 \\
$\mathrm{S}$ & $:$ 剥離線 (separation line) \\
$S$ & $:$ 参照面積 (機体底面面積), $\mathrm{nD}^{2 / 4}$ \\
$\mathrm{SW}$ & $:$ 衝撃波 \\
$T$ & $:$ 温度
\end{tabular}

\footnotetext{
*1 02010 日本航空宇宙学会

平成21年9月9日,第53回宇宙科学技術連合講演会において一部 発表. 平成 21 年 10 月 9 日原稿受付

*2宇宙航空研究開発機構 情報・計算工学センター

*3宇宙航空研究開発機構 宇宙科学研究本部

*4宇宙航空研究開発機構 固体ロケット研究チーム
}

\author{
下添え字 \\ 0 ：澱み条件 \\ $\infty \quad$ ：一樣流条件 \\ 1. は じめに
}

次期固体ロケットは, $\mathrm{M}-\mathrm{V}$ ロケットの技術を継承した上 で,簡素な打上げシステムによる小型衛星の効率的運用な どを目的として宇宙航空研究開発機構(JAXA)にて研究・ 開発が進められている ${ }^{1,2)}$. 現在, 弚の機体形状について 検討が行われており，弚の空力特性を知る事は打上げ能力 ・制御性解析・荷重解析等, システムの成立性を評価する 上で, 極めて重要である. 乥こで本研究では, 現行の機体

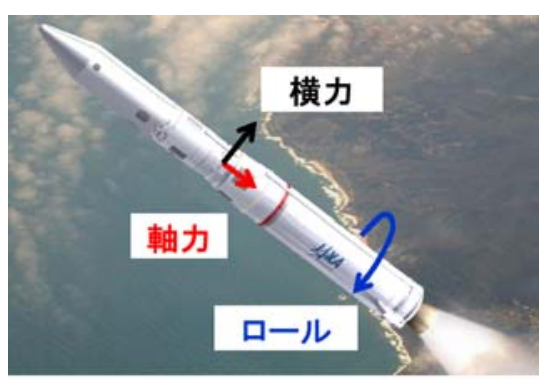

第 1 図次期固体ロケット ( $\mathrm{CG}$ 飛行イメージ) と主要な空力 特性 
第1表 風洞試験模型と試験ヶース

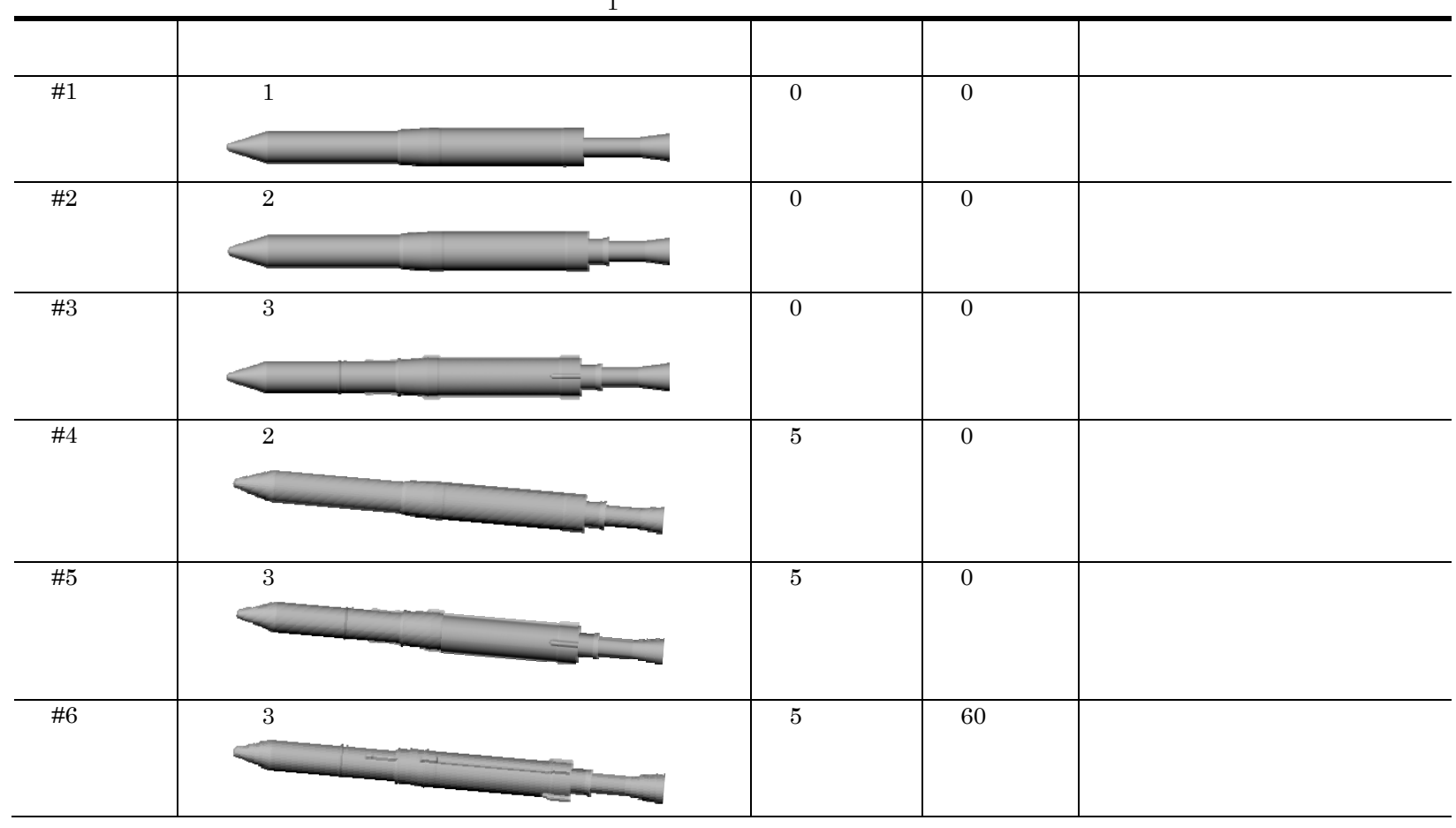

形状 (第1図) に対し風洞試験を実施し，圧力測定や可視 化試験により，マッハ数1.5における周囲の流れ場を調べ る.ここでマッ八数 $1.5 と は$, システム解析上厳しい条件 となる,飛翔中の動圧が最大となる時間帯のマッハ数であ る . このとき, 以下の3つの主要な空力特性に注目する .

1）軸力特性（抵抗特性; 迎角無し時)：打上げ能力 を評価する上で重要な要素 .

2）横力特性：ピッチノヨー制御力や，荷重条件を評 価する上で重要な要素 .

3）ロール特性：ロール制御力を評価する上で重要な 要素.

次期固体ロケットの空力特性については, 近い将来に数 值計算 (CFD, 数值流体力学) を実施し, 試験結果と併 用して詳細な解析を行う予定であり, 現在準備を進めてい る3).ここではまず，i）機体の持つ突起部やノズルが流れ 場や空力特性に及ぼす影響について基礎的な知見を得る と共に，ii）「実験で分かる事」と「CFDで解析しないと 分からない事」の線引きを行い, iii) CFDの検証に有用な データを取得する事を目的とする．なお， ベース圧補正 4 〜7)については, 別途検討するものとし ${ }^{8)}$, ここでは議論の 対象外とする.

\section{2 実 験 方 法}

21 試験模型および試験ヶース 次期固体ロケットの 機体 (全機) 形状は複杂倠であり, 樣々な突起部が非対称に 存在する (注 : ここでは簡単のため,「軸対称」である事 を「対称」と呼び, 光うでない場合すべてを「非対称」と 記す. 以下同じ）. 本風洞試験では, 第2図に示す 3 種類 の風試模型を用いた .すなわち, i) 模型1（突起部もノズ ルも無し）,ii）模型2（突起部無し，ノズル有り)，iii）模 型3 (突起部もノズルも有り：全機形状) である．ちなみ に風試模型のノズル形状は, 実際の機体に用いる形状 ${ }^{1)}$ と はやや異なる .これは, 天秤一スティングを挿入するため に必要な断面積をノズル内径として確保するためである が,ノズル底面の外径のスケールは，実機に乥ろえてある．

これらの風試模型を用い, 上述の目的に対し，第1表に 示す全6ケースの試験を行った．

22 風洞および測定項目 本研究では, JAXA/ISAS (宇宙科学研究本部) の吹き出し式超音速風洞を使用した (第3図). 計測部は $600 \mathrm{~mm} \times 600 \mathrm{~mm}$ で, 主流マッハ数 は, 次期固体口ケットが飛行経路上, 最大動圧条件に近く なる $M_{\infty}=1.5$ とした .ノズル部を含まない模型全長Lを基準 としたレイノルズ数は， $R e_{\infty} \mathrm{L}=1.2 \times 10^{7}$ である . また , 総

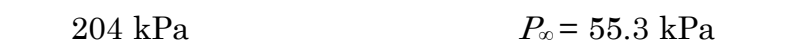
温は常温である (第2 表) . 通風中, 迎角は-15度〜+15

(a) 模型 1 (突起部無し, ノズル無し)

(b) 模型 2 (突起部無し, ノズル有り)

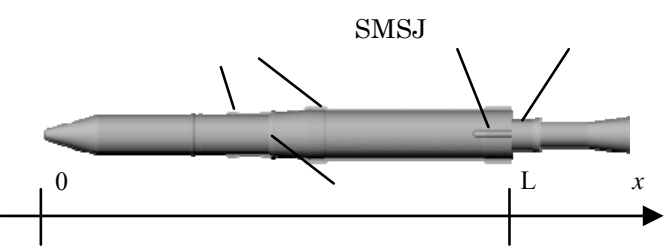

(c) 模型 3 (突起部有り，ノズル有り：全機形状) 第 2 图次期固体ロケット風試模型 
度と変化 (スウィープ) させたが, ここでは迎角無し(0 度) および有り (5 度で代表) の結果のみを示す．

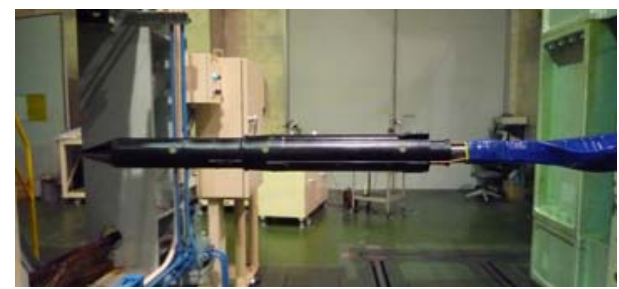

第 3 图超音速風洞と風試模型 : 風洞設置時

実験内容は, 天秤による六分力測定, 圧力センサによる ベース圧力測定, シュリーレン法およびオイルフロー法に よる流れの可視化である.シュリーレン可視化と六分力測 定，圧力測定は同時に行った .圧力測定には共和電業製の 圧力センサPA-2KB (許容値 : $200 \mathrm{kPa}$, 精度 : $\pm 0.2 \mathrm{kPa}$ ， 応答性 : $500 \mathrm{~Hz})$ を用いた。

オイルフロー可視化試験では, 二酸化チタンをオレイン 酸で溶き, 流動パラフィンで延ばしてオイルを作成（約 2:1:1の割合) し，黑色模型に塗布した . 通風中の動画と 通風後の静止画から，模型表面の流れパターンを解析した

通風時間は,シュリーレン可視化と圧力測定の場合は風 洞静定後 20 秒間とした .ただし上述のように実際の通風 中は迎角を変化させており, 各迎角における圧力は 0.1 秒 間中，21個のサンプリングデータ (標準偏差 $0.1 \%$ 未満) の平均值である .オイルフロー可視化の場合は，15秒間 通風した。

第2表 本風洞試験の通風条件: JAXA/ISAS (宇宙科学研究本部) 超音速風洞

\begin{tabular}{l|l}
\hline$M_{\infty}$ & 1.5 \\
$R e_{\infty \mathrm{L}}$ & $1.2 \times 10^{7}$ \\
$P_{0}[\mathrm{kPa}]$ & 204 \\
$T_{0}[\mathrm{~K}]$ & 298 \\
run time [s] & $15 \sim 20$ \\
\hline
\end{tabular}

\section{3. 結果と考察}

3.1 可視化試験結果 風洞試験によるシュリーレンお よびオイルフロー可視化結果と，兴れらに基づく流れ場の 概要図を，第4図〜第9図に示す (第9图はオイルフローの 結果のみ示す)．

3. 1. 1 シュリーレン可視化結果 まずシュリーレン結 果 (赤: 主流方向に圧縮, 青 : 膨張) より得られた全体的 な流れ場の概要を説明する .ケース\#1〜\#6のいずれの場 合も機体先端部および重心付近継手部より比較的強い斜 め衝撃波SW1およびSW $\mathrm{SW}_{2}$ 光れぞれ発生し, 風洞壁で反射 している様子が分かる.弚の後これらの衝撃波は模型へと 入射してくるが, 兴の位置はベース部よりも十分下流のス ティング部である.従って, 本研究の議論においては, 風 洞壁干渉9)の影響(なないものと判断した . ちなみに, 重心 付近継手部のやや後方に弓型に映っている衝撃波は, $\mathrm{SW}_{1}$
が風洞観測空に入射したものと考えられる.よって，風洞 壁からの反射衝撃波は概要図に示していない．

第4図 $a$ 第8図aを比較する限り，概して，ノズルや機 体突起部の有無による流れ場への影響は, 大域的に見れば 大きくない，模型3 (第6图，第8図) では機体突起部によ り複数の衝撃波か観察され，機体周囲の物理量は大きく変 化しているものと考えられるが，衝撃波 $\mathrm{SW}_{1}$ およびSW $\mathrm{SW}_{2}$ の位置や形態等はほぼ維持されている.

3.1.2オイルフロー可視化結果 次に, オイルフロー可 視化結果を比較する。ここで, 軸力特性に注目するケース \#1〜\#3では, ベース流れに焦点を絞った . 上述の広域的 なシュリーレン可視化結果と対照的に,ベース部では局所 的だか顕著な違いが見られた 。

ノズルの有無による影響 (ケース\#1 と\#2 の比較)

>ノズルの有無によらず対称な流れ場が得られてい る.特にノズル無しの場合の結果 (第 4 図 b 上) は, 文献 10)の類似形状に対する結果に近く，付着 線 $\mathrm{A}_{1}$ から录離線 $\mathrm{S}_{1}$ にかけて逆流構造が存在する と考えられる(第 4 図 b下)．

>ノズルの存在により, 機体底面直後 $\left(\mathrm{S}_{1}\right)$ のみならず， ノズル直後 $\left(\mathrm{S}_{2}\right)$ にも录離線が見られる(第 5 図 b) .

>ノズルの存在によりオイルのパターンや剥離線・ 付着線の位置はほとんど变化せず, ベース部流れ としての剥離長さ ( $\mathrm{S}_{1}$ と付着線 $\mathrm{A}_{1}$ の距離 機体底 面直径 D) にも顕著な変化は見られなかった．つ まり，ベース流れの主構造（付着線 $\mathrm{A}_{1}$ から剥離線 $\mathrm{S}_{1}$ への逆流構造) は, ノズルによって大きく变化 していない.

突起部の有無による影響 (ケース\#2 と\#3 の比較)

> 模型 3 (ケース\#3) では非対称な突起部の影響によ り，ベース部に非対称な流れ場が作られている。 特に，機体底面直後およびノズル直後の录|離線 $\mathrm{S}_{1}$, $\mathrm{S}_{2}$ も非対称となっている (第 6 图 $\mathrm{b}$ ) 。

> スティングにおける付着線 $\mathrm{A}_{1}$ は消失し, 代わりに 複数の節点(Nodal Points) $\mathrm{N}_{31}, \mathrm{~N}_{32^{11,12}}$ 力現れて いる.光してこれらを分断する形で，新たに流れ 方向に剥離線 $\mathrm{S}_{31}, \mathrm{~S}_{32}$ か現れている。

ケース\#4〜\#6 では軸力およびローリング・モーメント に注目するため,ベース部ではなく機体側面の流れ場につ いて考察する。

・迎角の有無による影響 (ケース\#2 と\#4の比較)

> 迎角の有無によらず流れは基本的に物体に沿って おり（＝側面にてロール方向への剥離が無い）， 大域的な流れ場の違いは生まれていない事が分か る (第 5 図，第 7 図).

>一方, 主流方向にはテーパー部で小さな剥離領域 があるものと見られる $\left(\mathrm{S}_{4}\right.$; 第 7 図 d) .ただしこ の剥離領域の形成は，迎角の有無によらない。 

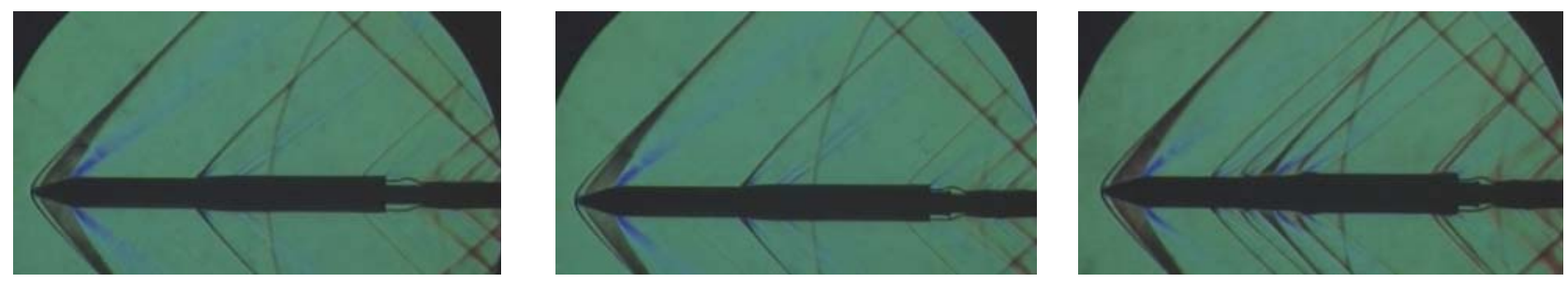

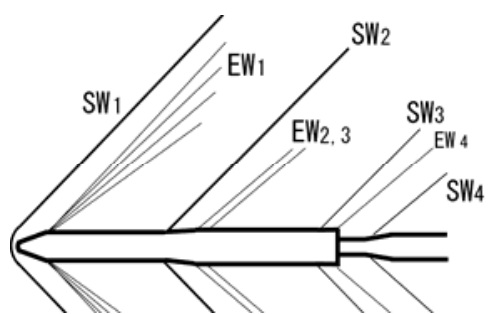

(a) シュリーレン

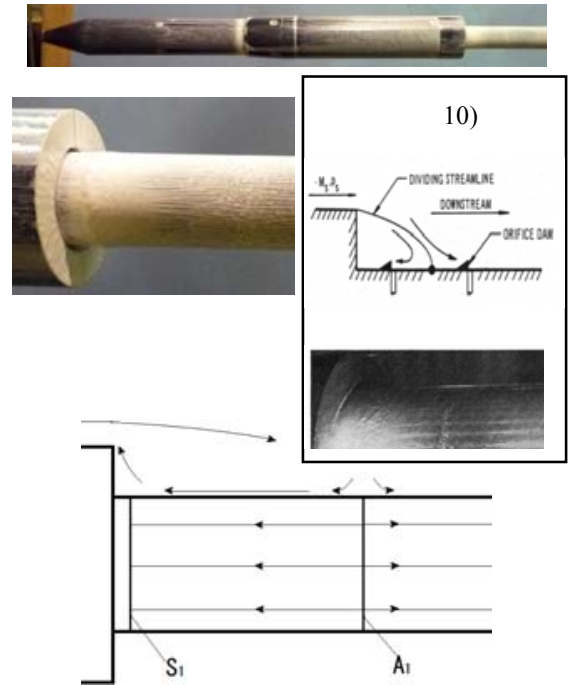

(b) オイルフロー

第 4 図風洞試験可視化結果 (上) と概要図

(下) - ケース\#1: 模型 1 (突起部 無し, ノズル無し)，迎角無し

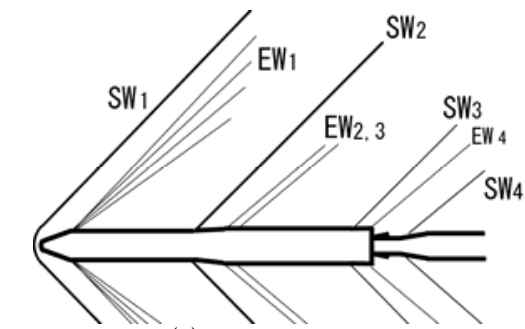

(a) シュリーレン
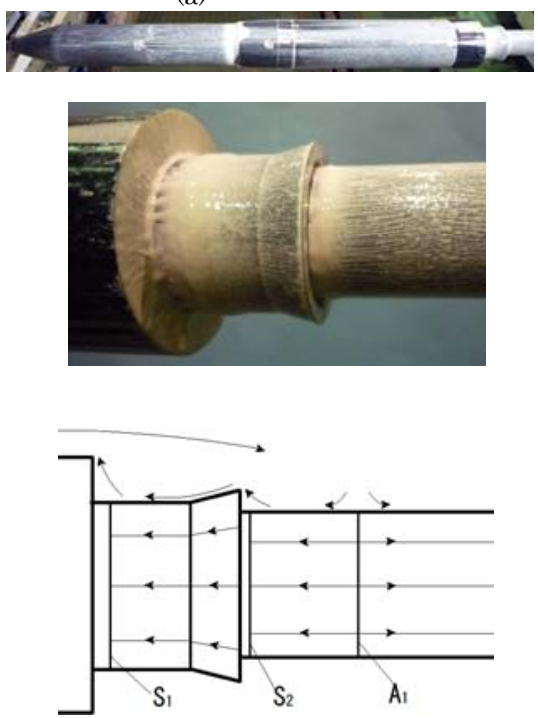

(b) オイルフロー

第 5 図風洞試験可視化結果 (上) と概要図 (下) - ケース\#2: 模型 2 (突起部 無し，ノズル有り），迎角無し

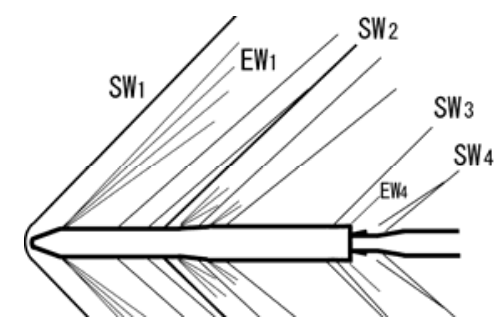

(a) シュリーレン
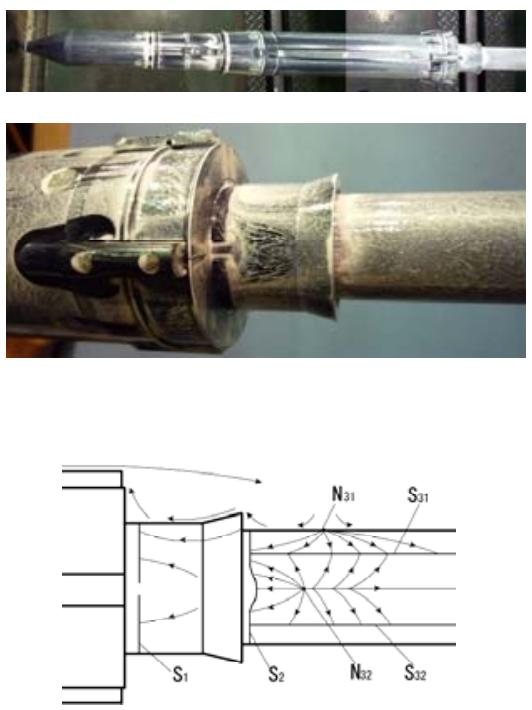

(b) オイルフロー

第 6 図風洞試験可視化結果 (上) と概要 図 (下) - ケース\#3: 模型 3 (全 機形状)，迎角無し
>一般に大規模剥離を伴う流れ場の CFDによる再現 は難しいが，このケースは (少なくとも側面流れ は）付着流としての扱いで十分と判断できる.

・迎角および突起がある場合 (ケース\#5 ; 第 8 图)

> 機体のフランジ (セグメント接合部のリング状の 突起) において風上側にのみ, 主流方向の剥離が 生じており，特徽的である $\left(\mathrm{S}_{4} \sim \mathrm{S}_{6} ;\right.$; 第 8 图 d)， この剥離の規模は比較的大きく，前方の別のフラ ンジにまで到達しているため, 剥離領域同士も干 渉し, 非常に複雑な流体現象か現れていると考え られる.この流体構造を実験結果から考察する事 は困難であり，CFDによる解析が有効であろう .

> 後部の突起 (SMSJ と呼ばれるサイド・ジェット 姿勢制御装置; 第 2 图 c 参照) 前方において衝撃 波が発生しているものと見られ，剥離 $\mathrm{S}_{7}$ か現れて いる(第 8 図 e,f) .このように機体から鈍頭形状 の部位が突出する場合には, 一般に馬蹄渦(horseshoe vortex) ${ }^{13}$ )が形成される事が知られており，こ
こでも同樣の渦構造が現れているものと考えられ る.これについては，後にCFDにより確認を行う 予定である。なお，この剥離 $\mathrm{S} 7$ は迎角無しの場合 にも現れていたが (第 6 図 b) , 迎角有りの場合に は，後述するように横力へ大きな影響を持つと考 えられる。

・ ロール角の有無による影響 (ケース\#5 と\#6 の比較)

> ロール角をつけると，機体表面に非対称に存在す る部材 (ケーブル・ダクトや SMSJ ; 第 2 図 c 参 照）に気流が非対称に衝突するため，側面（ロー ル方向) の剥離も見られるようになる(例えば， $\mathrm{S}_{4}$; 第 9 图 b) . 更に ,剥離渦同士が干渉するなど (例えば $\mathrm{S}_{5}$ と $\mathrm{S}_{8} ;$; 第 9 図 b) ，観察される流体現 象は極めて複雑であり，このケースも CFD による 解析が有効であろう.

\section{2 空気力測定結果}

3. 21 抵抗（軸力）第 10 図にケース\#1〜\#3において 測定された抵抗 (軸力係数 $C_{\mathrm{A}}=F\left(q_{\infty} S\right)$; 軸力 $F$, 一樣流 


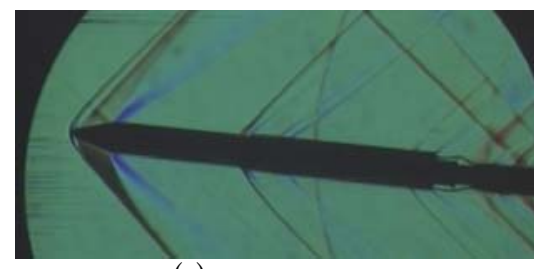

(a) シュリーレン

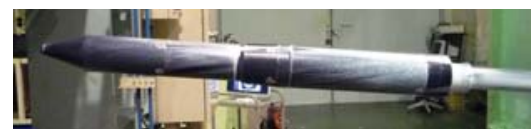

(b) オイルフロー (全体)

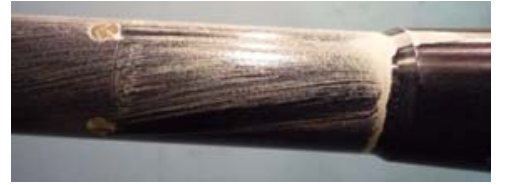

(c) オイルフロー (テーパー部; $0.3<x / \mathrm{L}<0.5$ )

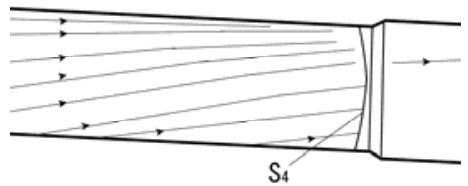

(d) 模式図 (テーパー部 ; $0.3<x / \mathrm{L}<0.5$ )

第 7 図 風洞試験可視化結果と概要図 - ケ 一ス\#4: 模型 2 (突起部無し, ) ズル有り），迎角有り

動圧 $q_{\infty}$ ，代表面積 $\left.S\right)$ を示す . この図より，ケース\#1 と \#2では抵抗値にわずかな差(約 $8 \%$ ) が見られた程度だが， ケース\#3では抵抗值がケース\#2 の約 1.6 倍と増大してい る事が分かる.この増大は, シュリーレンおよびオイルフ ロー可視化結果 (第 6 図) から明らかであるように,フラ ンジ, ケーブル・ダクト, SMSJ 等の突起部が作り出す衝 撃波による寄与を表しており，ノズルの影響に比べると， 1 オーダ大きい事が分かる. 過去の M-V ロケットの抵抗 測定結果 ${ }^{14)}$ においても, フランジのみによる抵抗の 3 割 近くの増大が報告されており, 同程度である.ただし，才 イルフロー結果（第 6 図 b) から明らかとなったように， ケース\#3 のベース流れは非対称性か強い.このため, べ 一ス圧および关れを用いて算出された抵抗值の定量的な 議論はここではこれ以上進めず, 今後 CFD により行う事 にする. 各突起部の抵抗への寄与分も，CFD で明らかに する予定である.なお, 前面抵抗やスティングが無い場合 の抵抗の算出についても , 別途検討の必要があり,今後の 課題である.

3. 22 横力 ケース\#4 (突起部無し, 迎角有り) およ び\#5 (突起部有り, 迎角有り) において測定された横力 (垂直力) 係数 $C_{N}$ (下記式(1)より求める) を迎角 $\alpha=1$ 度 〜10 度の範囲で第 11 図に示す .この図より, 突起の有無 によらず, 迎角 $\alpha=5$ 度以下では横力係数は迎角に対してほ ほ線形に变化しており(つまり,横力係数傾斜 $C_{N}$ dはほぼ 一定），光れ以上迎角が付くと徐々に非線形性の影響か現 れている事が分かる. 従って横力係数傾斜 $C_{N_{d}}$ は, 迎角 5

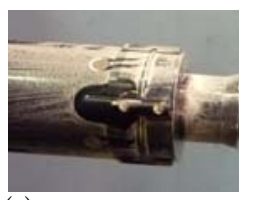

(e) オイルフロー(後 部 ;

$0.85<x / \mathrm{L}<1.05)$ (f) 模式図 (後部 ; $0.85<x / \mathrm{L}<1.05)$

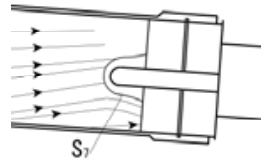

第 8 図風洞試験可視化結果と概要図 - ケ 一ス\#5：模型 3 (全機形状)，迎 角有り (続き)

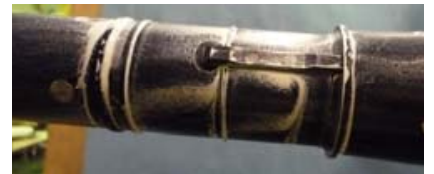

(a) オイルフロー (テーパー部; $0.3<x / L<0.5$ )

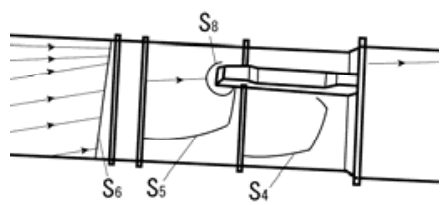

(b) 模式図 (テーパー部 ; $0.3<x / L<0.5$ )

第 9 図風洞試験可視化結果と概要図 - ケ 一ス\#6:模型 3 (全機形状)，迎 角有り，ロール角有り

度以下の低迎角の条件下では，例えば迎角 5 度における值 で代表させる事が妥当であると言える.なお，迎角 5 度に

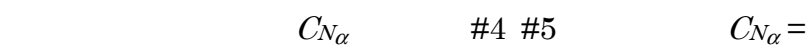
$2.58 \pm 0.10$ および $3.50 \pm 0.03$ であった .ここで, $C_{N}$ および $C_{N_{a}}$ は横力 (垂直力) $N$, 一樣流動圧 $q_{\infty}$, 代表面積 $S$, 光 して迎角 $\alpha=5$ 度を利用して，

$$
\left.\begin{array}{l}
C_{N \alpha}=C_{N} / \alpha[\mathrm{rad}] \\
C_{N}=N / q_{\infty} S
\end{array}\right\}
$$

より算出している.突起部の影響により，横力は約 1.4 倍 に増大している事が分かる.これは主に，機体後方の突起

(SMSJ) に迎角のある一樣流が衝撃波を伴って入射した ためと考えられる(第 8 图 e,f) .これらのデータは，今 後行う CFD の検証に利用する予定である ${ }^{3)}$.

3.23 ローリング・モーメント ローリング・モーメ ントは樣々な突起部の影響が互いにキャンセルし合い,結 果的に現れる值は極めて小さくなる事が知られている15). よってこれについては計測が困難であり，CFD によって

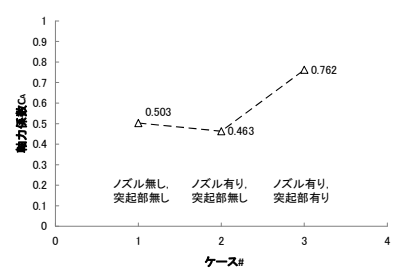

第 10 图 試験模型と軸力係数 $C_{\mathrm{A}}$

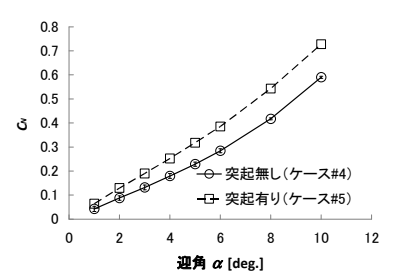

第 11 図 横力係数 $C_{\mathrm{N}}$ と迎角 $\alpha$ 
求める予定である ここのとき特に，ロケット左右に掛かる 值を弚れ光れ抽出し，現れうるローリング・モーメントの 最大值を求める.

\section{4. ま と め}

次期固体ロケットの空力特性解析を目的としてマッハ 数1.5の風洞試験を行い, 空力データを取得し, 以下の基 礎的知見を得た。

\section{流れ場について \\ >ノズルの影響 : ノズルの有無により機体周りの流 れ場に顕著な変化は見られない．ベース流れにつ いても，「スティングに付着した流れが機体底面 まで遡る」という主要な構造は変化していない．}

$>$ 機体突起部の影響：突起により多くの衝撃波が生 じ，機体周囲の物理量は変化していると考えられ るが , 突起部無しの場合に現れていた流れ場の主 構造は維持されている．ただし，突起部が非対称 である事から，弚の下流の流れ場も非対称となり， ベース流れは大きく変化している．

$>$ 迎角の影響 (突起無し) : 迎角が 5 度付く事によ って流れ場は大きく変化しない．特に，ロール方 向への剥離は発生しない。

$>$ 迎角の影響（突起有り）：迎角が 5 度付く事によ り，流れ場の大きな変化は見られないが，フラン ジ付近などで局所的な変化は見られた．例えば， 風上側にのみ, フランジ上流で主流方向およびロ 一ル方向に大きな录離が見られた 。

>ロールの影響：ロール角が付き, 突起部の主流に 対する角度が変化する事により，フランジにおけ る主流方向への剥離とケーブル・ダクトにおける ロール方向への剥離の干渉と言った，極めて複杂倠 な流体現象か現れた。

空力特性について

>ノズルの影響：抵抗 (軸力) への影響は小さく，\% のオーダである

$>$ 機体突起部の影響: 抵抗や横力がそれぞれ約 1.6 倍および約 1.4 倍 (迎角の有る場合：下記) 増大.

> 迎角の影響 : 横力データを取得した結果, 突起無 しの場合は $C_{N_{\alpha}}=2.58 \pm 0.10$,突起有り (全機形状) では $3.50 \pm 0.03$ であった．これらの值は，迎角 5 度以下においてほぼ一定である．また後者の増分 は, 主に後部突起に迎角を持った一樣流が衝撃波 を伴って入射するためと考えられる．これらは今 後，CFD の検証に用いる予定である ${ }^{3)}$ 。

- 前面抵抗やスティングが無い場合の抵抗の算出方法 についても，別途検討の必要がある．

今後は数値解析を実施し, 上記の知見を元に，流れ場や 空力特性についてより詳細に調べる予定である.更に実際 の設計にはレイノルズ数, ノズル形状 , ノズルからのプル 一ム排気の影響も考慮する必要があり，今後の課題である
本研究の風洞試験を遂行するに当たり，JAXA固体ロケ ット研究チームの三保和之氏,田村誠氏，宇宙科学研究本 部の大屋友児氏, 藤井孝藏研究室の大山聖助教のこ協力を いただいた .同じく藤井孝藏研究室滑慶則氏,山崎祐希氏， 浅田健吾氏,野々村拓氏には本研究に関わる試計算を実行 していただき，有意義な議論を交わした．藤井孝藏教授， JAXA情報・計算工学センター (JEDI) 堤誠司氏には貴 重なこ指摘をいただいた .ここに感謝の意を表する(上記 所属は全て，風洞試験を実施した2009年5月当時)．

\section{参 考 文 献}

1）森田泰弘，井元隆行，羽生宏人，大塚浩仁，固体口ケッ卜研 究チーム：次期固体ロケットの開発，第52回宇宙科学技術連 合講演会，1J01，2008

2）井元隆行，森田泰弘，羽生宏人：次期固体ロケットの開発計 画，第 53 回宇宙科学技術連合講演会，1B01， JSASS-2009-4019, 2009

3）北村圭一, 藤本圭一郎, 野中 聡, 入門朋子, 福添森康, 葛 生和人，嶋英志：次期固体口ケット空力特性についての風洞 試験と数值解析, 平成 21 年度宇宙航行の力学シンポジウム, 2009

4）藤本圭一郎，北村圭一，嶋 英志，滑 慶則，山崎祐希，山 本誠, 浅田健吾 : 次期固体口ケットの抵抗特性解析 - 抵抗予 測精度についての一考察 - , 平成 20 年度宇宙航行の力学シン ポジウム , pp.128-131, 2008.

5) Forsythe, J.R., Hoffmann, K.A., Cummings, R.M., and Squires, K.D.: Detached-Eddy Simulation with Compressibility Corrections Applied to a Supersonic Axisymmetric Base Flow, J. Fluids Engineering, 124 (2002), pp.911-923.

6）只熊憲治, 麻生 茂, 谷 泰寛, 溝口也寸志, 岡田卓三 : 磁 力支持天秤による切り立った底部を有する機体のBase圧補 正に関する研究，日本航空宇宙学会論文集，53(2005)， pp.562-568

7) Pope, A. and Goin, K.L.: High-Speed Wind Tunnel Testing, John Wiley \& Sons, Inc., New York, 1965, p.323.

8）北村圭一, 藤本圭一郎, 野中聡, 福添森康, 入門朋子, 嶋英 志 : 次期固体ロケット抵抗特性についての風洞試験および解 析，第 53 回宇宙科学技術連合講演会，1B08， JSASS-2009-4026, 2009 .

9) Garbaruk, A., Shur, M., Strelets, M., and Spalart, P.R. Numerical Study of Wind-Tunnel Walls Effects on Transonic Airfoil Flow, AIAA J., 41 (2003), pp.1046-1054.

10) Roshko, A. and Thomke, G.J.: Observations of Turbulent Reattachment behind an Axisymmetric DownstreamFacing Step in Supersonic Flow, AIAA J., 4 (1966), pp.975-980.

11) Hunt, J.C.R., Abell, C.J., Peterka, J.A. and Woo, H.: Kinematical Studies of the Flows around Free or Surface-Mounted Obstacles; Applying Topology to Flow Visualization, J. Fluid Mech., 86 (1978), pp. 179-200.

12) Lighthill, M.J.: 2.6 Attachment and Separation in ThreeDimensional Flows, Rosenhead, L., ed., Laminar Boundary Layers, Oxford University Press, Oxford, 1963, pp. $72-83$.

13) Stollery, J.L.: Some Aspects of Shock-Wave BoundaryLayer Interaction Relevant to Intake Flows, Paper 17 in AGARD Conference Proceedings, No. 428, Aerodynamics of Hypersonic Lifting Vehicles, 1987.

14）井浦秀一，藤井孝藏，林光一：CFDによるM-Vロケットの抵 抗算定，平成10年度宇宙航行の力学シンポジウム，1998.

15）飯塚宣行, 藤井孝藏, 藤松信義, 守屋公一郎：M-Vロケット 5 号機ロールモーメント特性のCFD解析，第35回流体力学講 演会，2003。 